\title{
Three Cases of Exclusively Extragenital Canine Transmissible Venereal Tumor (cTVT)
}

\author{
Jéssica Fontes Veloso', Thais Nascimento de Andrade Oliveira', Lorena Priscila Andrade', \\ Fabiana Lessa Silva², Katia Moema Oliveira Rosa Sampaioº, Ana Flávia Ribeiro Machado Michel², \\ Mário Sergio Lima de Lavor² \& Renata Santiago Alberto Carlos ${ }^{2}$
}

\begin{abstract}
Background: Canine Transmissible Venereal Tumor (cTVT) is a neoplasia that affects mainly the genital organs of dogs, but can rich extragenital sites as well. It's a tumor characterized microscopically by the presence of vacuolized round cells. Transmission occurs by implantation of these cells in non-affected tissues and the treatment is based on vincristine chemotherapy. Cases: Case 1. A 5-year-old intact male Poodle, presenting an increase volume of nasal plane came for veterinary care at a private veterinary clinic. The animal had bilateral bloody nasal secretion and dyspnea. The external genitalia had no alterations. The cytological evaluation confirmed cTVT. Treatment with vincristine sulfate weekly showed a rapid response with improvement of the respiratory condition, total remission of the mass and absence of neoplastic cells in cytology. Case 2. A 5-year-old mixed-breed canine bitch, weighing $6.7 \mathrm{~kg}$, was brought to the State University of Santa Cruz Veterinary Hospital (UESC-VH), showing an increase volume in the nasal plan region, with complaints about sneezing, nasal bleeding, respiratory distress with approximately 4 months of evolution. The owner informed that the mother of these female dog, that lived in the same environment, died a month before the beginning of clinical signs of the bitch of this case, and showed a reddish vaginal mass with intense bleeding. Intranasal exfoliative cytology showed moderately cellular sample compatible with cTVT. The treatment with vincristine sulphate for 6 weeks, showed completely remission of all clinical signs. Case 3. A 3-year-old mixed-breed male dog was brought to the UESC-VH with a reddish, friable mass located in the left eye. The citology confirmed the clinical suspicion of cTVT. After six weekly sessions of chemotherapy with vincristine sulfate, the tumor regressed and a new cytological evaluation was performed, without visible of tumor cells. By the end of the treatment, the dog was diagnosed with phitisis bulbi, and one year later, due to recurrent ulcerative keratitis, the enucleation was performed and the histopathological examination of the eye did not identify the presence of tumor cells. Discussion: Two of the dogs cited in this report had freely streets access, without supervision of the owners, and they are likely to have contracted cTVT on one of those occasions. The animal's care style acts as a risk factor for the development of neoplasia. Regarding the third animal, the close contact with another female dog, who had compatible vaginal cTVT clinical signs was probably the factor that determined the transmission. None of the animals cited in this report had lesions on their external genitalia. The extragenital presentation may be attributed to the social behavior of licking and sniffing the genitalia of carrier animals, which may lead to the natural implantation of the viable cells of the cTVT into the ocular and nasal mucosa. About the clinical signs manifested, in the cases of involvement of the nasal structures, the main signs described in literature are bloody nasal secretion, sneezing, dyspnea and increased nasal plane volume, and are similar to those observed in the animals cited in this report. In the case of ocular cTVT, the increase volume with impairment and deformity of all ocular structures, as well as pain and pruritus corroborate with the clinical findings observed in the literature. The cytopathological test was the diagnostic tool used in all cases cited in this report and the cytopathological findings corroborates with those described in the literature. Vincristine sulfate is the drug of choice for the treatment of cTVT cases, and in the dogs of this report, this drug was successfully used leading to complete remission of lesions and clinical signs, as observed in other studies.
\end{abstract}

Keywords: nasal mucosa, ocular mucosa, venereal disease, round cells. 


\section{INTRODUCTION}

The cTVT is a neoplasia that affects mainly the external genital region, but can be found in extragenitals organs as nasal, oral and ocular mucosa $[2,9,10,15]$. It has a cosmopolitan distribution [14] with a higher incidence in dogs that live on the streets or have access to the streets without supervision [7]. Metastasis are uncommon, occurring on average in 5\% of cases [14].

Because its transmission characteristic is by tumor cells implantation, this neoplasia is usually related to the presence of the concomitant genital form. However, there are reports of involvement of the nasal, oral, cutaneous and ocular mucosa exclusively $[2,9,10]$.

Macroscopically it presents as simple or multiple nodules with cauliflower-like appearance, friable and intense reddish color $[7,12,14,15]$. Microscopically presents round cells with delimited cytoplasmic borders, oval and often eccentric nuclei, granular chromatin and prominent nucleoli [1]. The nucleus:cytoplasm ratio is high, cytoplasm discreetly basophilic with multiple vacuoles, besides present in anisocytosis, anisocariosis, nuclear hyperchromasia and macrocariosis. Inflammatory cells and mitotic figures are also present $[1,16]$.

Diagnosis is made with physical examination, external genitalia inspection, and association with cytology and/or histopathology [1]. The aim of this study was to report three cases of extragenital cTVT with no genital involvement.

\section{CASES}

Case 1. A 5-year-old intact male Poodle, presenting an increase volume of nasal plane (Figure 1A) came for veterinary care at a private veterinary clinic. The animal had bilateral bloody nasal secretion and dyspnea. The owner informed that approximately 10 days before, the dog was submitted to a surgical procedure to remove a mass located inside the left nostril, which was not submitted for histopathological evaluation. Additionally the owner said that the animal had unattended access to the streets. The external genitalia had no alterations (Figure 1B). The patient was submitted to physical examination and in view of the observed alterations, aspiration cytology, facial x-ray, complete blood count (CBC) and biochemistry were requested.

During the cytological evaluation it was observed an intense population of round cells, with moderately mild basophilic cytoplasm containing multiple vacuoles of varying sizes in most cells; the nuclei were rounded, large, centrally located or in an eccentric position, with granular chromatin and one to two evident nucleoli. The mitotic index was moderate. The cytological findings were compatible with cTVT (Figure 1C). In the radiograph, it was noticed an increase volume located above the nasal bone, without bone involvement. The $\mathrm{CBC}$ and biochemical tests showed values within the normal ranges.

Treatment with vincristine sulfate (Fauldvin$\left.\mathrm{cri}^{\circledR}\right)^{1}$ was intravenously (IV) applied at a dose of $0.7 / \mathrm{m}^{2}$ every 7 days for a total of five sessions. Weekly CBC were performed prior to the chemotherapy sessions, in order to assess the animal's clinical conditions and whether or not chemotherapy would be performed.

A quickly clinical response was observed with improvement of the respiratory condition, total remission of the mass and absence of neoplastic cells in cytology. The animal was monitored after 12 months and did not present recurrence.

Case 2. A 5-year-old mixed-breed canine bitch, weighing $6.7 \mathrm{~kg}$, was brought to the State University of Santa Cruz Veterinary Hospital (UESC-HV) showing an increase volume in the nasal plan region (Figure 2A), as well as complaints about sneezing, nasal bleeding and respiratory distress with approximately 4 months of evolution. During this period, the animal was treated with $30 \mathrm{mg} / \mathrm{kg}$ of amoxicillin and clavulanate potassium $\left(\text { Clavulin }{ }^{\circledR} \mathrm{BD}\right)^{2}$ and $1 \mathrm{mg} / \mathrm{kg}$ of Prednisone $\left(\text { Meticorten }{ }^{\circledR}\right)^{3}$ due to suspected allergic conditions, as well as with $5 \mathrm{mg} / \mathrm{kg}$ of doxycycline (Doxitrat $\left.{ }^{\circledR}\right)^{4}$ every $12 \mathrm{~h}$ for 21 days due to the suspicion of ehrlichiosis. The owner informed that the mother of these female dog, lived in the same environment, died a month before the beginning of clinical signs of the bitch of this case, and showed a reddish vaginal mass with intense bleeding. Therefore, it was suspected to be a case of extragenital cTVT in the nasal sinus without involvement of the genital tract (Figure 2B). Intranasal exfoliative cytology (Figure 2C), simple skull radiography in the ventral-dorsal and lateral positions and CBC were requested.

The hematological tests showed values within the normal ranges. The radiographic examination showed a mass diverting the nasal septum to the left side and diminished visualization of the turbinated bones. In the exfoliative cytology, was observed a moderately cellular sample composed of individualized large round 


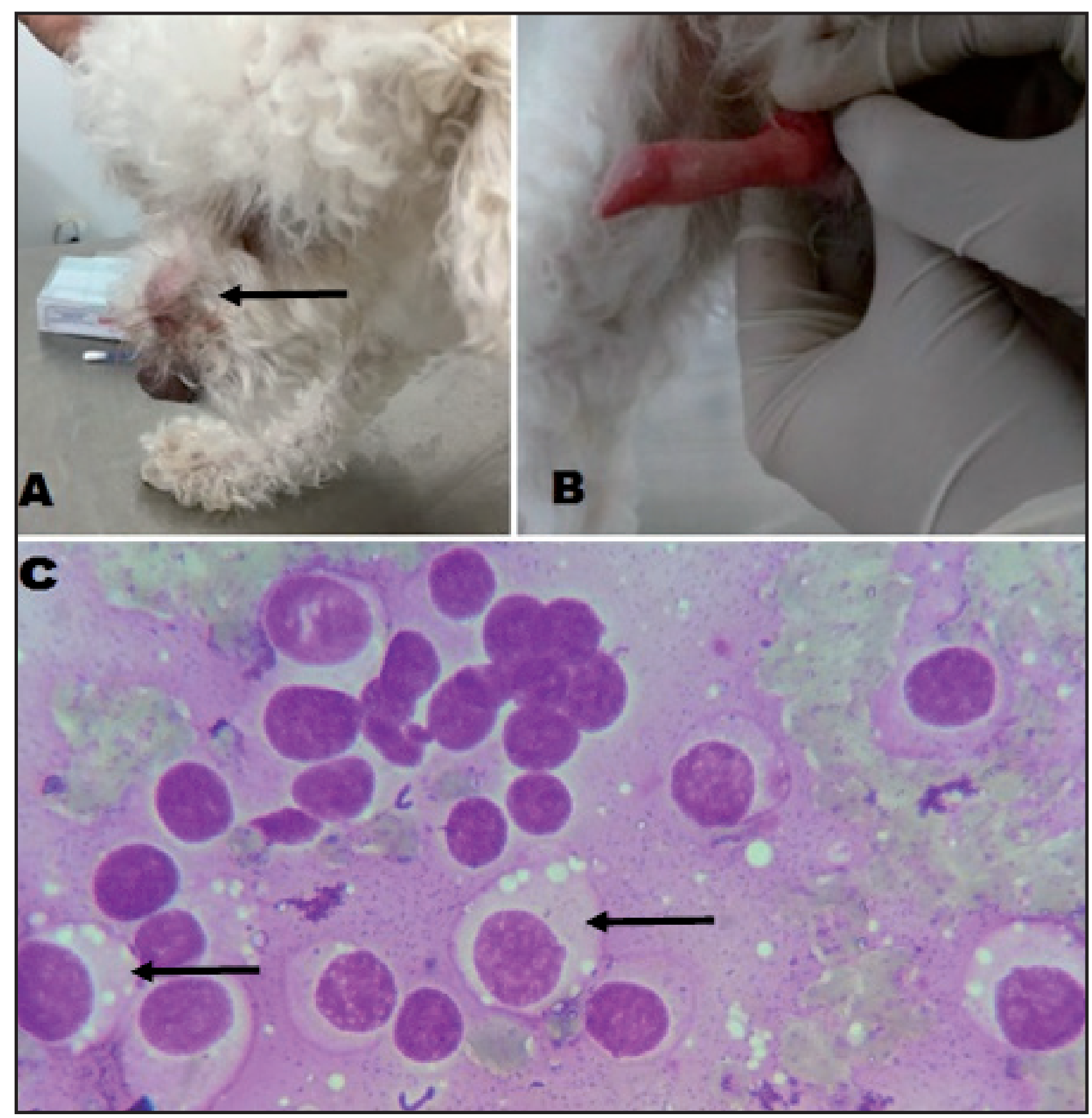

Figure 1. A- Photographic image demonstrating mass in the topographic region of the nose (arrow). B- Photographic image of the animal's penis without alterations. C- Aspiration photomicrography of the mass located in the nasal plane showing cTVT cells (arrows). [1000x].

cells. The cells had abundant, slightly basophilic cytoplasm with well-defined borders, often with clear peripheral vacuoles; the nuclei were rounded, large, central or eccentric, with granular chromatin, sometimes with evident nucleolus. The cytological characteristics were compatible with cTVT.

A treatment of vincristine sulfate (Fauldvin$\left.\mathrm{cri}^{\circledR}\right)^{1}$ was intravenously applied weekly at $0.7 \mathrm{mg} /$ $\mathrm{m}^{2}$ body weight, for 6 weeks, with remission of all clinical signs. A weekly blood count was performed immediately prior to the chemotherapy sessions to assess the animal's clinical condition and whether or not chemotherapy would be performed. At the end of the treatment, a new exfoliative cytology was performed and did not identify any remaining tumor cells. The animal was monitored after 12 months and did not present recurrence.

Case 3. A 3-year-old male mixed-breed dog, was brought to the UESC-HV with a reddish, friable mass located in the left eye. As the case 1, the animal had freely streets access and the owner informed that the tumor appeared 2 months before, gradually increasing 


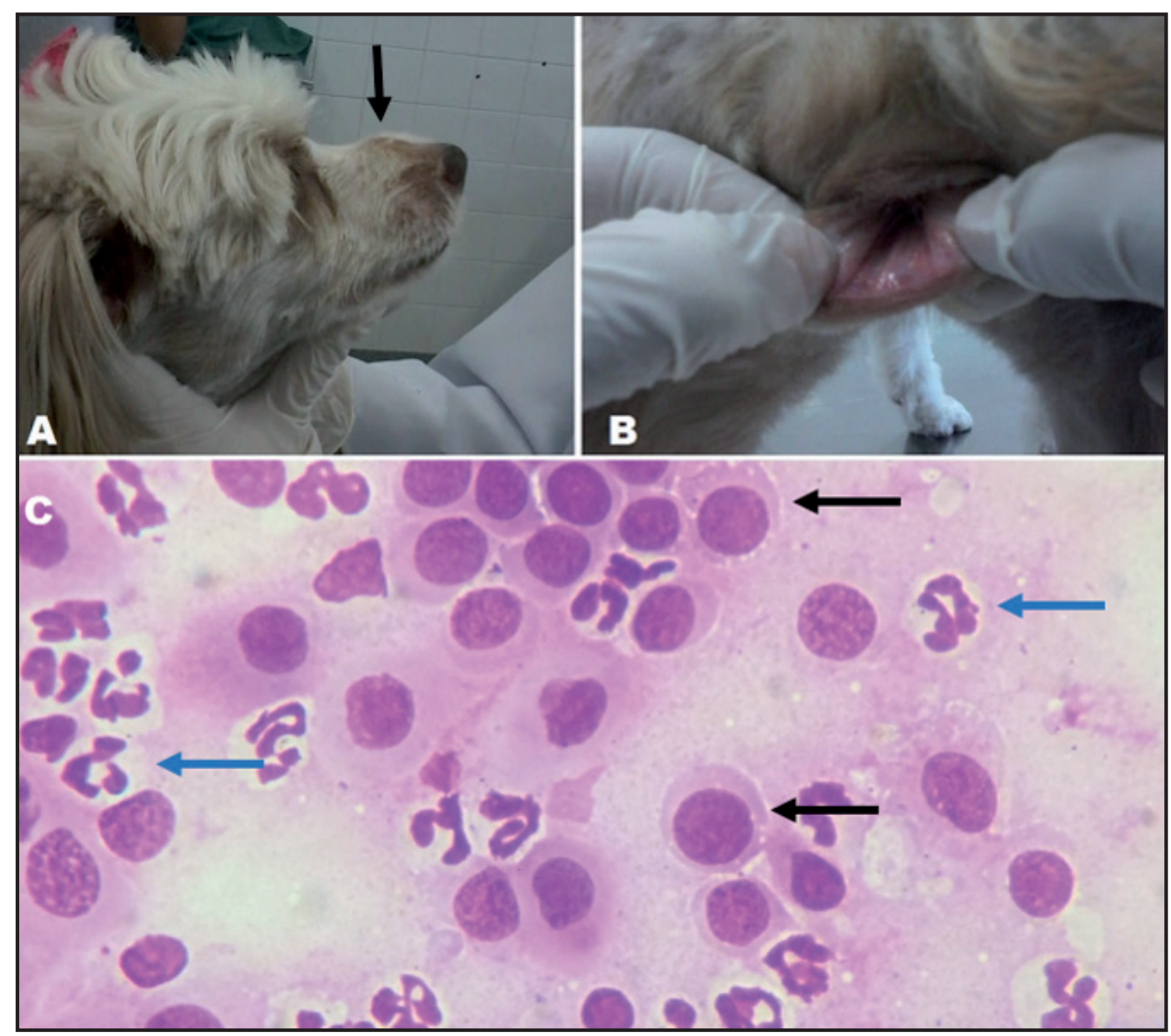

Figure 2. A- Photographic image demonstrating mass in the topographic region of the nose (arrow). B- Photographic image of the animal's vulva without alterations. C- Photomicrography of the mass aspirate located in the muzzle region showing cTVT cells (black arrows) and inflammatory infiltrate composed of segmented cells (blue arrows). [1000x].

its size until occupying the entire surface of the eye, preventing adequate eyelid cooptation. It was also reported that the animal had been treated for genital cTVT 1 year before, with only three chemotherapy sessions with IV vincristine sulfate $\left(\text { Fauldvincri }^{\circledR}\right)^{1}$ but the owner was not able to report the applied dose. The animal showed local itching, sensitivity to touch but nevertheless was feeding normally, with normal feces and urine.

Physical examination revealed a mass in the left eye, with no pathological alteration in the right eye (Figure 3A). CBC, ocular ultrasonography, imprint and fine needle aspiration cytology of the mass were requested. The hemogram showed leukocytosis (38000/ $\mathrm{mm}^{3}$ ) with neutrophilia. The cytology confirmed the clinical suspicion of cTVT, which was represented by an intensely cellular sample composed of large indivi- dualized round cells, with moderate anisocytosis and anisokaryosis. The cells had abundant, slightly basophilic cytoplasm with well-defined edges with clear peripherals, round, large, central or eccentric nuclei with granular chromatin, sometimes with evident nucleolus (Figure 3C). Ultrasonographic examination showed the presence of intraocular tumor with dislocation of intraophthalmic structures (Figure 3B).

Based on the diagnosis, it was established a protocol of chemotherapy treatment based on vincristine sulfate $\left(\text { Fauldvincri }^{\circledR}\right)^{1}$ at a dose of 0.7 $\mathrm{mg} / \mathrm{m}^{2} \mathrm{IV}$, consisting of 6 weekly sessions and with weekly follow-up with ocular US. At this time, topical eye drops therapy with 1 drop every $12 \mathrm{~h}$ of sodium diclofenac $0.1 \%\left(\text { Still }^{\circledR}\right)^{5} ; 1$ drop every $12 \mathrm{~h}$ of atropine sulfate $1 \%$ (Atropina $\left.^{\circledR}\right)^{5}$ and 1 drop every $3 \mathrm{~h}$ of $0.3 \%$ 
tobramycin $\left(\text { Tobrex }^{\circledR}\right)^{6}$ was also applied. After the first chemotherapy session, there was a regression of approximately $60 \%$ in the tumor size, with a reduction in leukocyte count $\left(16,800 / \mathrm{mm}^{3}\right)$. After the third session, there was a significant new reduction in the size of the mass allowing the closing of the affected eye. After the fourth chemotherapy session, there was a reduction in hematocrit value $(32.2 \%)$ and a slight increase in leukocyte counts $\left(24,000 / \mathrm{mm}^{3}\right)$, which were normalized at the end of the treatment. Weekly CBC were carried out, immediately prior to chemotherapy sessions in order to assess the animal's clinical conditions and whether or not chemotherapy would be performed. On the day of the sixth session, a new cytological evaluation was performed, without visible tumor cells and the ultrasonography did not identify the presence of intraocular mass. By the end of the treatment, the dog was diagnosed with phitisis bulbi in the affected eye.

As per the choice of the owner, the eyeball enucleation surgery at the end of the treatment was not performed, and the patient was followed up quarterly. One year after cTVT treatment ends, the owner decided to perform the enucleation surgery, since the eye had frequent secretion due to recurrent ulcerative keratitis. The surgical procedure occurred without complications and the histopathological examination of the eye did not identify the presence of tumor cells, confirming the efficacy of the treatment.

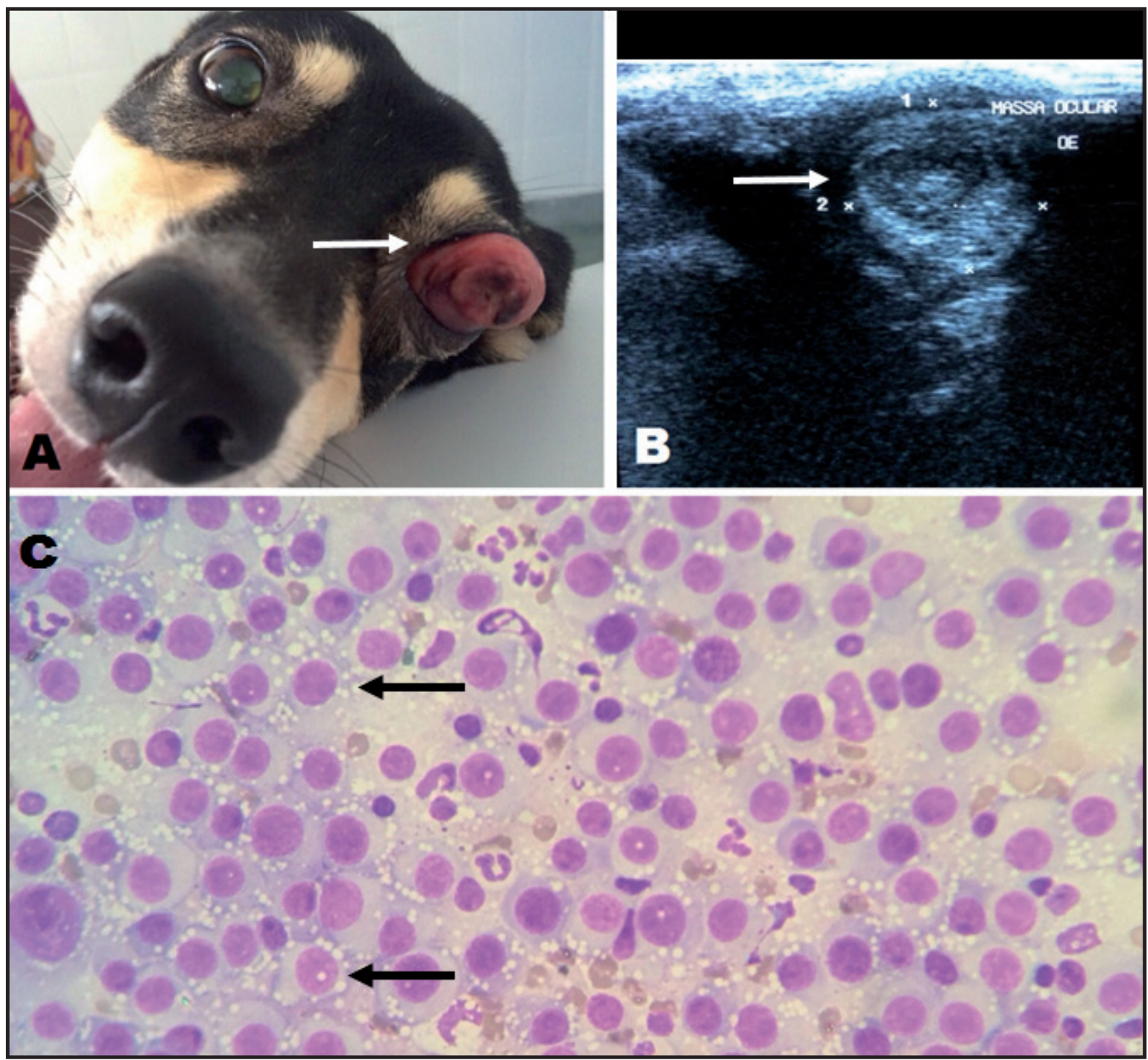

Figure 3. A- Photographic image demonstrating a reddish mass in the topographic region of the left eye (arrow), right eye without involvement. B- Ultrasound image of intraocular mass in the left eye (arrow). C- Photomicrography of mass cytology located in the left eye showing cTVT cells (arrows). [400x]. 


\section{DISCUSSION}

The cTVT is a potentially malignant neoplasia $[6,17]$, directly transmitted from dog to dog through the implantation of viable tumor cells on the surface of damaged mucous membranes [8]. The disease has worldwide distribution, with a higher prevalence in regions that have less control over their canine population [5,6]. Classically, neoplasia becomes evident in the external genitalia of dogs of both genders and coitus is considered the main form of transmission [15]. However, this tumor can be found in extragenital sites such as cutaneous tissue, nasal cavities [11], eyes [13] and more rarely in the central nervous system [3].

During the anamnesis, it has been informed that 2 of the dogs cited in this report had access to the streets without supervision of the owners, and they are likely to have contracted cTVT on one of those occasions. The animal's care style acts as a risk factor for the development of neoplasia, and dogs that have freely streets access are more exposed to contact with wandering dogs, which are the usual transmission agents of neoplasia [7]. Regarding the second animal reported, the close contact with another female dog, who had compatible vaginal cTVT alterations was probably the factor that determined the transmission.

In all cases cited in this report, the age of manifestation of neoplasia varied between 3 and 5 years, considered a period of greater reproductive activity and therefore, the phase of higher incidence of the disease $[1,15]$. Although coitus is considered the main form of transmission [15], sexually immature dogs can be affected when in contact with another carrier of neoplasia [1]. None of the animals cited in this report had lesions on their external genitalia. The extragenital presentation may be attributed to the social behavior of licking and sniffing the genitalia of carrier animals, which may lead to the natural implantation of the viable cells of the cTVT into the oral, ocular and nasal mucosa even when the animal does not have neoplasia in the genitalia [15].

Several studies have demonstrated the nasal cavity as the extragenital most frequently affected site by cTVT when in absence of primary genital tumor. In a study conducted with 144 animals with cTVT, $3.5 \%$ of the cases presented lesions in the nasal cavity [7]. On the other hand, the ophthalmic structures are the less frequently affected extragenital site, and when these structures are affected it is generally due to implantation of the neoplastic cells and not by metastasis, as observed in literature [2,10]. Hence, it has been suggested that in the case of the male dog with ocular cTVT, transmission occurred by implantation from direct contact with the genital lesion of another affected animal, since no metastasis have been observed. In addition, there was a greater impairment of external structures such as sclera and cornea, which reinforces this possibility. Although we have observed disruption of intra-ocular structures, the fact that tumor growth occurred over two months, it may have led to the infiltration of tumor cells into the eye. In the case of intraocular metastasis, the initial involvement of the vascular mesh such as the iris, ciliary body or choroid, and pattern of intraocular development would be expected [10,13], which did not occur in this case.

The clinical signs manifested in the animals with cTVT vary according to the location where neoplasia manifests [7]. In the cases of involvement of the nasal structures, the main signs described in literature are bloody nasal secretion, sneezing, dyspnea and increased nasal plane volume $[7,15]$ and are similar to those observed in the animals cited in this report. In the case of ocular cTVT, the volume increase with impairment and deformity of all ocular structures, as well as pain and pruritus corroborate with the clinical findings observed [12].

The complementary tests did not present significant alterations. Only the animal with ocular cTVT that presented leukocytosis with neutrophilia, probably due to tumor ulceration and secondary bacterial infection, which in turn may have been aggravated by the owner's delay in seeking medical-veterinary care. Alterations in CBC usually only occurs in situations in which the tumor becomes necrotic and infected or when metastasis occur [8].

The cytopathological test was the diagnostic tool used in all cases cited in this report. This test is considered the method of choice for suspected cases of cTVT because it is a simple, rapid, minimally invasive, painless and low-cost technique [1]. The cytopathological findings observed in the cases of this report corroborate with those described [16], which describe cTVT cells as oval rounds with clear cytoplasm containing vacuoles, also round or oval, often eccentric, variable-sized nuclei with coarsely granular chromatin and evident nucleoli. 
Vincristine sulfate is the drug of choice for the treatment of cTVT cases, because it has antimitotic effects with inhibition of cell proliferation [4]. In the dogs of this report, this drug was successfully used leading to complete remission of lesions and clinical changes, as observed in other studies [6,7]. It is important to notice that the treatment success was achieved by the use of a correct dose of the drug and the institution of multiple chemotherapy sessions. The initially choice for surgical treatment is not recommended because during the procedure, transplantation of the neoplastic cells to other sites may occur [9].

\section{MANUFACTURERS}

${ }^{1}$ Libbs Farmacêutica Ltda. São Paulo, SP, Brazil.

${ }^{2}$ GlaxoSmithKline Brasil Ltda. Rio de Janeiro, RJ, Brazil.

${ }^{3}$ Merck Sharp \& Dohme Farmacêutica Ltda. Campinas, SP, Brazil.

${ }^{4}$ União Química Farmacêutica Nacional S/A. Embu-Guaçu, SP,

Brazil.

${ }^{5}$ Allergan Produtos Farmacêuticos Ltda. Guarulhos, SP, Brazil.

${ }^{6}$ Alcon Laboratórios do Brasil Ltda. São Paulo, SP, Brazil.

Declaration of interest. The authors report no conflicts of interest. The authors alone are responsible for the content and writing of paper.

\section{REFERENCES}

1 Amaral A.S., Gaspar L.F., Silva S.B. \& Rocha N.S. 2004. Diagnóstico citológico do tumor venéreo transmissível na região de Botucatu, Brasil (estudo descritivo: 1994-2003). Revista Portuguesa de Ciências Veterinárias. 99(551): 167-171.

2 Amaral A.V., Oliveira R.F., Silva A.P., Baylão M.L., Luz L.C. \& Sant'ana F.J. 2012. Tumor Venéreo Transmissível Intra-ocular em cão: Relato de Caso. Revista Veterinária e Zootecnia. 19(1): 79-85.

3 Ferreira A.J., Jaggy A., Varejão A.P., Ferreira M.L., Correia J.M., Mulas J.M., Almeida O., Oliveira P. \& Prada J. 2000. Brain and ocular metastases from a transmissible veneral tumour in a dog. Journal of Small Animal Practice. 41(4): 165-168.

4 Greatti W.F.P., Amaral A.S., Silva S.B., Gaspar L.F.J., Barbisan L.F. \& Rocha N.S. 2004. Índices proliferativos do tumor venéreo canino transmissível pelas técnicas do CEC e KI-67 na citologia aspirativa com agulha fina. Archives of Veterinary Science. 9(1): 53-59.

5 Horta R.S., Viana A.A.S., Queiroz A.T., Lavalle G.E., Araújo M.R. \& Araújo R.B. 2012. Diagnóstico diferencial entre sarcoma histiocítico e tumor venéreo transmissível com disseminação extragenital - relato de caso. Revista Clínica Veterinária. 17(1): 96-102.

6 Horta R.S., Fonseca L.S., Miranda D.F.H., Quessada A.M., Rocha Neto H.J. \& Silva S.M.M.S. 2014. Tumor venéreo transmissível (TVT) com metástase para a glândula mamária. Acta Scientiae Veterinariae. 42(1): 1-6.

7 Huppes R.R., Silva C.G., Uscategui R.A.R., De Nardi A.B., Souza F.W., Tinucci Costa M., Amorim R.L., Pazzini J.M. \& Faria J.L.M. 2014. Tumor Venéreo Transmissível (TVT): Estudo Retrospectivo de 144 casos. ARS Veterinária. 30(1): 13-18.

8 Lorimier L.P. \& Fan T.M. 2007. Canine Transmissible Venereal Tumor. In: Withrow S.J. \& Vail D.M. (Eds). Small Animal Clinical Oncology. 4th edn. Philadelphia: Elsevier, pp.799-804.

9 Marcos R., Santos M., Marrinha C. \& Rocha E. 2006. Cutaneous transmissible venereal tumor without genital involvement in a prepubertal female dog. Veterinary Clinical Pathology. 35(1): 106-109.

10 Milo J. \& Snead E. 2014. A case of ocular canine transmissible venereal tumor. The Canadian Veterinary Journal. 55(1): 1245-1249.

11 Park M., Kim Y., Kang M., Oh S., Cho D., Shin N. \& Kim D. 2006. Disseminated transmissible venereal tumor in a dog. Journal of Veterinary Diagnostic Investigation. 18(1): 130-133.

12 Pereira J.S., Silva A.B., Martins A.L., Ferreira A.M. \& Brooks D.E. 2000. Immunohistochemical characterization of intraocular metastasis of a canine transmissible venereal tumor. Veterinary Ophthalmology. 3(1): 43-47.

13 Rodrigues G.N., Alessi A.C. \& Laus J.L. 2001. Tumor venéreo transmissível intra-ocular em cão. Ciência Rural. 31(1): 141-143. 
14 Santos R.L. \& Alessi A.C. 2016. Patologia Veterinária. 2.ed. Rio de Janeiro: Roca, 856p.

15 Tinucci-Costa M. 2009. Tumor venéreo transmissível canino. In: Daleck C.R., De Nardi A.B. \& Rodaski S. (Eds). Oncologia em cães e gatos. São Paulo: Roca, pp.539-555.

16 Varaschin M.S., Woufers F., Bernins V.M.O., Soares T.M.P., Tokura V.N. \& Dias M.P.L. 2001. Tumor venéreo transmissível canino na região de Alfenas, MG: formas de apresentação clínico patológicas. Revista Clínica Veterinária. 6(32): 332-338.

17 Woods J.P. 2013. Canine Transmissible Venereal Tumor. In: Withrow S.J., Vail D.M. \& Page R.L. (Eds). Withrow \& MacEwen's Small Animal Clinical Oncology. 5th edn. St. Louis: Saunders, pp.692-696. 